\title{
The problems and countermeasures in the information technology education of teachers
}

\author{
HU Zhongying \\ Continue education college, Wenzhou City University, Wenzhou China \\ 359895779@qq.com
}

\begin{abstract}
The construction of the learning society, we must make use of information technology education. With the revolutionary impact of information technology on the development of education, whether information technology can really promote the development of education, the key belongs to the field of information technology education practice areas in the information technology education of teachers, teacher, I combine the Lucheng District, Wenzhou Teachers information technology literacy investigation to clarify the connotation of teachers information technology education and information technology education of teachers professional attitude, professional knowledge, professional competence, and proposed to focus on integration of information technology and teacher learning, to enhance teachers' information literacy, promote information technology dialysis teaching integration, to enhance the effectiveness of classroom teaching countermeasures..
\end{abstract}

Keywords- Information technology; Educational technology; Information Technology Education; Countermeasures

\section{INTRODUCTION}

National long-term education reform and development program (2010-2020), "By 2020, the basic realization of modernization of education, basically forming a learning society, into the ranks of the country rich in human resources," and pointed out that "information technology education development revolution impact, we must attach great importance to the formation of the "learning society, relying solely on traditional education can not be satisfied, requires the help of information technology education, sharing of educational resources in order to truly build a learning society. Whether information technology can really promote the development of education, the teachers, the key is whether effective teachers of information technology and teaching depth fusion. Areas of practice areas, for information technology education of teachers belong to information technology education, the author of Lucheng District, Wenzhou Teacher information technology literacy survey, an attempt to explore the connotation of teachers in information technology education, problems and countermeasures.

\section{THE CONNOTATION OF TEACHERS IN INFORMATION TECHNOLOGY EDUCATION}

The concept of teachers in information technology education in our country is still not clearly defined. the education technology is not the same as information technology, education, technology, and information technology have their own areas, each to be a collection of the intersection of both the Education and information technology. Can be understood as the application of information technology in the field of education (IT in Education). 1994 United States Educational Communications and Technology Institute (AECT) educational technology (referred to as ET) madea definition: "teaching techniques to promote learning about the process and the resources to design, development, utilization, management and evaluation theory and Practice. "information technology (referred to as IT) is involved in information gathering, processing, storage, and other electronic technology, digital technology, computer technology, communication technology, network technology, the general term. Educational technology is equivalent to the application of information technology in education, should be greater than the former (ET), including the application of IT in education. I believe that the so-called teachers in information technology education teachers integrated use of modern information technology and teaching in-depth integration, it mainly includes the professional attitude of the teachers in information technology, combination and use of professional knowledge and ability, as well as teachers of information literacy.

\section{PROBLEM IN THE INFORMATION TECHNOLOGY EDUCATION OF TEACHERS}

This study selected 68 teachers in Lucheng District of Wenzhou City, as the survey, carried out a small-scale survey. The survey topics included closed-ended questions and open-ended questions two. And written questionnaires instructed the recovered scene investigation. The survey questionnaire of 68,68 were recovered, recovery rate of $100 \%, 65$ valid questionnaires were $95 \%$ efficiency. In the survey were men and 15 accounted for $22 \%$ female and 53 $(78 \%)$. Statistical results are as follows:

\section{A. Professional attitude problem of the use of information technology education teachers}

Teachers attitudes to information technology or acceptable levels, the impact will improve his information technology skills and the application of information technology in education, teaching practice. "You understand the extent of information technology?" The results are shown in Table 1: 
table 1. teachers' understanding of information technology (\%)

\begin{tabular}{|c|c|c|}
\hline $\begin{array}{c}\text { Familiar } \\
\text { with } \\
\text { information } \\
\text { technology }\end{array}$ & $\begin{array}{c}\text { Understanding of } \\
\text { information technology } \\
\text { Technique }\end{array}$ & $\begin{array}{c}\text { information } \\
\text { technology poorly } \\
\text { understood }\end{array}$ \\
\hline 28 & 60 & 12 \\
\hline
\end{tabular}

The data show that $88 \%$ of the teachers are familiar with or understand information technology, they think it is very important to the application of information technology in their own teaching work, can significantly improve the effectiveness of teaching. $12 \%$ of the teachers heard but do not understand the information technology specific, older faculty. This shows the positive attitude of teachers in the use of information technology.

For the main purpose of your usual Internet what? "The results are shown in Table 2:

Table 2. The main purpose of Table 2 Teachers Internet

\begin{tabular}{|c|c|c|c|c|}
\hline $\begin{array}{c}\text { Investigations } \\
\text { related }\end{array}$ & Chat & $\begin{array}{c}\text { Playing } \\
\text { games or } \\
\text { watching } \\
\text { movies }\end{array}$ & $\begin{array}{c}\text { Read the } \\
\text { news }\end{array}$ & Other \\
\hline 25 & 28 & 35 & 12 & 10 \\
\hline
\end{tabular}

The data show that only $25 \%$ of the teachers are learning data access, while $75 \%$ of people in order to chat, play games or watch movies Internet. Internet we can see, feel mostly some teachers aimed at Leisure.

\section{B. Teachers expertise in the use of information technology}

The survey shows that: teachers on basic computer knowledge and software is relatively familiar with $88 \%$ of the teachers are more familiar with the PowerPoint, $86 \%$ of the teachers are familiar with the Windows operating $90 \%$ of the teachers are familiar with word processing software Word, 48\% of teachers are familiar with word processing softwareExcel, relatively speaking, teachers familiar with Flash, Authorware, Visual Basic, C language, FrontPage, Photoshop, etc. is minimal.

information technology knowledge of teachers are poorly understood, and only $41 \%$ of teachers able to use Taobao, Dangdang buy books, etc., and the effective use of information technology to solve problems in the work, life, and most of the teachers can not use information technology to solve work, life, and thus hinder the ability of teachers to use information technology to solve problems.

\section{Teachers to use information technology professional competence}

"Your use of multimedia in teaching computer teaching it?" The results are shown in Table 3: table 3. Teaching teachers to use multimedia computer

\begin{tabular}{|c|c|c|}
\hline $\begin{array}{c}\text { Frequent use } \\
\text { of } \\
\text { multimedia } \\
\text { teaching }\end{array}$ & $\begin{array}{c}\text { Sometimes use the } \\
\text { multimedia teaching }\end{array}$ & $\begin{array}{c}\text { Occasional use of } \\
\text { multimedia teaching }\end{array}$ \\
\hline 25 & 58 & 27 \\
\hline
\end{tabular}

The data show that $58 \%$ of the teachers sometimes use, $25 \%$ of teachers often use $27 \%$ of the teachers used only occasionally. Interviews, some teachers think that the lack of preparation of the the CAI instructional design experience, and another before class lesson planning large, teachers' work pressure is the main reason of the teachers to use information technology teaching. From the point of view of multimedia computer skills, teachers should have the the computer operating capacity, the ability to use the network, and create a simple multimedia courseware skills. However, the findings are not optimistic about $5 \%$ of the teachers to be able to produce courseware Authorware courseware. Teachers learning awareness, information technology operations skills improve slower, most of the teachers in the production and application of courseware level is relatively low, the lack of effective integration of information technology in teaching

\section{COUNTERMEASURES ON THE INFORMATION TECHNOLOGY EDUCATION OF TEACHERS}

The information age to education has injected new vigor and vitality, had a profound impact on education, but also put forward higher requirements. In particular, the application of information technology in education, accelerate the pace of information technology in education. The teachers in both information technology and education being educated, and implementers of information technology education, information technology education of teachers should not only be concerned about the technology and its applications, under conditions of informatization should be more concerned about the teachers' professional development.

\section{A. focus on the integration of information technology and teacher learning, to enhance teachers' information literacy}

Teacher education acts mainly by their education ideological With the advent of the information age, education, information technology is the ever-present impact on teachers' old concepts of education, faced with this kind of impact, teachers must be updated concepts of education. "Opinions" of the Ministry of Education to promote teacher education informatization construction requirements: teacher education must accelerate the process, and increase efforts to the construction of information technology, has laid a solid foundation for the comprehensive primary and secondary school teachers to improve the information literacy. Enhance teachers' information literacy learning through a variety of ways. One should pay attention to the theoretical knowledge of 
information technology learning seriously learning instructional design theory of knowledge, teachers only to master the basic theoretical knowledge of information technology, was able to spirit better teaching. Second, we need to actively carry out research related to the information technology, combine the theoretical study and practical action, reflection in action, in the use of information technology tools to improve information technology literacy. Third, it is necessary to actively participate in a variety of forms of learning, self-learning, participatory, experiential, case, task type, and strive to improve the learning effectiveness. Online education for teachers to learn to open up a new way, through online education online learning, constant contact with the new mode of teaching in the online education environment, instructional media courseware, becoming familiar with information technology through the study and practice operations to enhance their information literacy.

\section{$B$. promoting the integration of information technology and teaching, and enhance the effectiveness of classroom teaching}

Teachers should be good to integrate IT education resources. Strengthen the IT education of teachers is an urgent need for teachers in the process of education information development. The face of the numerous the huge educational information resources, teachers want to know how to determine the mission objectives, how to determine the method of searching for information on how to locate and access to information, and how to determine the relevance of the information, and how to solve the problem of information organization and communication. To this end, teachers only exposure to the real environment based on a wealth of learning resources in order to cultivate a strong ability. Information technology environment mainly refers to the infrastructure and resources, including a multimedia presentation in the classroom, network classrooms for distance education information network system and teaching resources. Teachers should be teaching resource development and application designers, organizers and practitioners, to be good at the development and integration of teaching resources, especially teaching information resources development and utilization, to a large extent to be able to effectively improve the effectiveness of teaching. Mainly from the following aspects to the development and use of teaching resources: information technology and curriculum integration; effective classroom instructional design; design of learning activities; effective use of teaching information resources.

\section{CONCLUSIONS}

The teachers should be adept at IT teaching. A particularly important part of the information technology in education is to promote the integration of IT and teaching. Integration of IT teaching teachers to use a combination of IT guiding students to learn the teaching process, combine
IT resources, methods and course content in the teaching process to complete a teaching methods of the teaching task. The process of integration in the IT and teaching, the teachers according to the different disciplines, content level, and inquiry learning methods require the application of a variety of teaching modes to support the implementation of the instructional design process. Modes such as problem-based learning, project-based learning, networking, personalized learning model, resource-based learning model, a typical case-based learning model teaching model. Characteristics of their teaching, teaching structure, teaching aspects of the steps to follow the the IT teaching of law. Each teaching mode has its own strengths, it is only valid for a specific teaching and learning, there is no the Almighty teaching mode an applicable everywhere. Similarly, each teaching mode and inevitably there are also limitations, is not conducive to teaching and learning. Only in certain teaching situations, a teaching mode than another teaching model more effectively. Teachers in the design of integrated solutions to select the appropriate teaching mode, in order to enhance the effectiveness of the teaching.

\section{REFERENCES}

[1] Ministry of Education, educational technology competency standards (Trial) ", 2004.12.25

[2] Ministry of Education, the Ministry of Education to promote teacher education informatization construction advice 2002.2.27

[3] Lan Henan. Innovation, research and development: standards and integration of educational technology - China Educational Technology Association 2004 Annual conference of the [J]. Educational Technology Research, 2005

[4] Ren Lili. Comparison of educational technology and information technology with education and information technology development $[\mathrm{J}]$. Education and Information Technology, 2006

[5] Li Jiahou third National Education Technology Plan and Revelation Ming Journal of Distance Education .2005. 